\title{
PUBLIC PROCUREMENT AS INNOVATION POLICY: THE CASE OF THE BRAZILIAN OILAND GAS SECTOR
}

\author{
Carlos Frederico Leão Rocha
}

\begin{abstract}
$\underline{\text { Resumo }}$
Estudiosos da inovação e elaboradores de política têm reservado intensa atenção à existência de políticas de compras como forma de aumentar o esforço inovador e de fornecer o ambiente adequado à inovação, incentivando a interação entre firmas e outras organizações. Este artigo objetiva aferir o efeito da política de compras da Petrobras no contexto da política de conteúdo local no setor de petróleo e gás durante o governo Lula. Usando microdados da RAIS, o artigo compara o desempenho dos fornecedores de equipamentos da indústria do petróleo e gás com uma amostra de controle obtida pelo uso de técnicas de propensity score matching. Os resultados sugerem que ser um fornecedor do setor aumenta o esforço inovador da empresa. $\mathrm{O}$ artigo sugere que o esforço tecnológico dos fornecedores é 2.5 pontos percentuais maior do que a amostra de fornecedores. Esse resultado sugere que a política foi bem-sucedida e que maior atenção deve ser dada a instrumentos de política pelo lado da demanda.
\end{abstract}

Palavras chave: política de inovação; política de compras; petróleo e gás; Brasil

\section{Abstract}

Students of innovation policy and policymakers have been increasingly giving attention to procurement policy as a form of enhancing innovative effort and providing an adequate environment for interactions between innovative firms and organizations. This paper aims to assess the effect of procurement policy performed by Petrobras under the local content policy in the oil and gas sector of Lula's government. Using microdata from RAIS, the paper compares the performance of oil and gas equipment supplies firms with a control sample built through the use propensity score matching techniques. The results suggest that being a supplier to the sector improves firm's innovative effort. The paper estimates that Petrobras' suppliers ratio of technological personnel to total number of employees is 2.5 percentage points above the control sample. This result suggests that policy has been successful and further attention should be directed towards demand instruments.

Keywords: Innovation policy; procurement policy; oil and gas; Brazil

JEL: O38; L52 


\section{INTRODUCTION}

For many years, scholars and policymakers have downplayed the role of demand in innovative settings. As a consequence, innovative policy has mostly been directed towards correcting market imperfections on the supply side. Innovative instruments such as public subsidies to innovation, tax credits and public financing have been the main channels used by policymakers (Edquist and Hommen 2000, Edler and Georghiou 2007 and Guerzoni and Raiteri 2015). Whenever applied, demand side policies have remained as a hidden agenda of what has been called an entrepreneurial state. In these cases, governmental agencies and state companies have acted as coordinators of a network of suppliers (Block 2008 and Mazzucato 2011).

Petrobras, the Brazilian state-owned oil company (SOC) has since its birth been a state instrument for the development of downstream and upstream firms. Cardoso's administration reduced Petrobras' focus on suppliers' development and the importance of Petrobras' demand to domestic industrial companies. However, during the two Lula administrations, the resurgence of quality control programs and of domestic suppliers' innovative developed was coupled with a national content policy that increasingly established national content goals.

It is clear that this shift in public policy may have had consequences in firms' conduct. It is imperative to know if policy had impact in firms' innovative strategies. This paper aims to assess the effect of demand oriented policy performed by Petrobras under the national content goals established by Agência Nacional do Petróleo (ANP). The paper uses microdata from Registro Administrativo de Informações Sociais (RAIS) in order to create a quasi-experimental setting through the building of a counterfactual sample through propensity score matching. After forming the control sample, we run Schumpeterian based models to assess the impact of procurement policy on innovation efforts.

The paper is organized in six sections, including this introduction. Section two presents an analytical framework based on previous literature on the subject and defines the contribution of this paper. Section three describes the national content policy in the oil and gas sector and the instruments Petrobras has designed to cope with the task of domestic acquisition of materials and services. Section four describes the database and presents the methodology used in the paper. Section five presents the results and section six shows the conclusions.

\section{ANALYTICAL FRAMEWORK}

Two different views usually motivate innovative policies. On the one hand, there are those who understand policies should be designed to correct for market imperfections; on the other 
hand, there are those that perceive government intervention as a builder of networks. The first perception of innovative policies is generally focused on correcting market imperfections, such as uncertainty or lack of appropriablity. Proposed mechanisms are typically the structuring of property rights instruments and the correction of market prices under the effect of externalities. In this case, resources may be channeled through the financing of R\&D activities, the building of financial mechanisms and institutions, such as venture capital funds, the supply of nonreimbursable funds or the implementation of subsidies and tax exemptions for innovative activities.

The second perception emphasizes the interactive character of innovative activities and stresses the importance of structuring innovative networks. Emphasis is directed towards the interaction between different set of actors such as universities, research institutions, small and large firms. Supply and demand tend to be linked. The role of network coordination and governmental procurement in technological development has long been known. One should thus distinguish between direct and indirect innovation policies (Edquist, Hommen and Tsipouri 2000). In the first case, policy instruments pursue the enhancement of innovative activities through general changes in the institutional framework, in the second case, instruments aim to develop interaction. In the latter setting, public organizations are directly involved in pursuing and building interaction.

Two factors have however been responsible for overshadowing government procurement. On the one hand, the demand-pull-technology-push debate of the 80's downplayed the importance of demand and emphasized the protagonism of supply factors in innovative settings (Dosi 1982, Scherer 1982). On the other hand, demand policies also suffered resistance from those oppose picking the winner policies and from restrictions that emerge from WTO agreements (Edler and Georghiou 2007).

Empirical evidence did however favor government procurement policies. Litchenberg (1987) tests the effect of federally financed R\&D on R\&D expenditures. He, however, controls for sales derived from government procurement. He concludes that the real effect on company R\&D expenditures does not departure from governmentally funded R\&D but from government procurement. This conclusion is clearly associated with increases in future revenues and therefore with the potential of public procurement to positively affect $R \& D$ expenditures. Lichtenberg (1988) used a sample of 165 companies, controlling for industry characteristics and time variables, to test whether competitive or non-competitive government procurement affects company R\&D expenditures. He concludes for a positive effect of government procurement, much larger than other policy instruments. Geroski (1990) also finds evidence for the good performance of public procurement. Guerzoni and Raiteri (2015) control for possible interaction 
between a diversity of supply policy and demand policy instruments, arriving to a similar conclusion as Litchenberg that whenever controlled for demand policy instruments, supply policy tend to reduce its effectiveness and that demand policy instruments remains relevant.

Most importantly, there has been a number of recent studies that have renewed the interest in procurement policy due to the possibility of interaction between agents that procurement may provide (Mazzucato 2011, Block 2008 and Edler and Georghiou 2007). More specifically, Block (2008) argues that the US has kept hidden a developmental State that has implemented a series of successful interventions. According to his research, the results are unchallenged and a large number of the main innovations in the US have followed projects that were funded by governmental agencies.

However, government procurement may be approached by different angles and may not consist in an innovative policy. Guerzoni and Raitieri (2015) define public procurement innovation policy as the one where a public agency places and order for products that do not exist at the time, but could be delivered if interaction with the public agency takes place. In the Brazilian context, nonetheless, one should consider that it not necessarily involves novelty to the international market, but in the market context where these firms carry out their activities. More adequately, Edquist and Hommen (2000) list a set of instruments that may be present in these settings and that enhance innovative efforts. First, innovation procurement policies may provide early sophisticated demand for domestic firms. This means that new services and products that would not be otherwise demanded or that would only be demanded through exports may find a new demand in the public sector. Second, procurement may set stringent patterns and benchmarking for domestic firms. Quality control may be implemented. Third, procurement policy may encourage domestic firms "to act as 'lead users' in setting leading-edge standards for domestic producers" (Edquist and Hommen p. 62) and therefore contribute to international competitiveness of domestic industry. Fourth, and maybe most importantly, procurement policy should facilitate innovation and should emphasize the complementary strengths of firms in different positions of the product chain and seek the coordination of their actions, stimulating the establishment of linkages and flows of knowledge amongst firms and other organizations. Fifth, it should stimulate competition. Competitive dynamics is important to offer the tensions needed for innovation inducement and for a health network of innovative actors.

\section{NATIONAL CONTENT POLICY IN THE OIL AND GAS SECTOR IN BRAZIL}

National content policy and their framing under Lula's government represented a major step towards the establishment of a public procurement policy in the Brazilian oil and gas sector. National content clauses have been present in oil and gas exploration and production contracts since the first bidding round that took place in 1999 (president Cardoso's second term). The 
main purpose of local content requirements were "to allow locally established goods and service providers to participate in the oil and gas supply chain and increase their market share in a competitive basis” (ANP 2012). ${ }^{1}$

Until the fourth round, the clause established preference to domestic suppliers, but did not have any particular national content target. Rounds five and six contracts, that took place in 2003 and 2004 (in president Lula's first term), established minimum percentages based on whether blocks were located onshore, offshore shallow water or offshore deep water. In 2005, authorities established a methodology to measure local content. In 2007, minimum and maximum local content levels were established per equipment. This regulation still holds up to today. Thus, regulation became stricter as time went by. Moreover, monitoring became tighter and ANP has been playing an increasing role in this matter. ${ }^{2}$ More importantly, local content has begun to play a central role in oil and gas policy in Brazil and the fulfillment of these requirements have become a central concern for policy makers, oil companies and major suppliers.

In order to measure national content, authorities have developed a rule book to be followed by oil and gas suppliers from the $7^{\text {th }}$ round on. This rule books submits to certification every item and sub item acquire by oil and gas companies activities and their EPCs in their exploration and production. National content targets are established per item and sub item. This trend towards stricter local content requirements has been criticized and later on we should deal with it.

Petrobras, the Brazilian NOC, is the main oil operator in Brazil, producing around $90 \%$ of total oil. Up to 2013, it held the third largest R\&D budget amongst the world's oil and gas operators and had the largest R\&D to sales ratio (see Rocha 2015). Petrobras acts in almost every stage of the oil and gas production chain, such as exploration, production, refining and transportation. Most importantly, Petrobras' activities in exploration and production involve the development of new technology to achieve deep water and ultra-deep water oil production, being also the only company that operates in pre-salt conditions. These features is important to settle that Petrobras operates in challenging and innovative conditions.

One important issue about the general use of local content policies in Brazil is whether Petrobras has been able to positively influence suppliers' learning and knowledge accumulation process. IPEA (2011) tried to provide an answer to this question. They show that, on average, Petrobras's suppliers are larger, have a larger percentage of scientific personnel, engineers, greater wages and better education. Therefore, Petrobras' suppliers are amongst the most

\footnotetext{
${ }^{1}$ Procurement policy does not distinguish locally established multinational affiliates from domestic capital firms.

${ }^{2}$ Regulation ANP no. 9/2007 establishes the frequency, the format and the content of local investments reports made with exploration and production development activities
} 
qualified firms in the Brazilian economy. So, one important question would be whether Petrobras adds value to its suppliers. De Negri et al. (2011) use propensity score matching techniques to define a control group with respect to a set of characteristics. Analyzing the treated sample (Petrobras suppliers) against the control sample, they find that Petrobras' procurement has positive and continued effect on firm growth, labor force education level and wages (which may be an indicator for productivity). They however find a negative impact on exports. Though no test is run by De Negri et al. (2011), this negative effect may be result of the redirecting of resources towards the greater opportunities provided by Petrobras.

It is true that Petrobras chooses better firms. A supplier certificate (CRCC) that authorizes departments to acquire goods or services has to be issued. Apart from formalities associated with the legal status of firms, Petrobras requires social responsibility, environmental and health certifications (respectively, ETHOS, ISO 14001 and ISO 18001). If the supplier provides critical products, product quality certification (ISO 9001) is required. Very often firms enhance their market value when they obtain CRCC from Petrobras. ${ }^{3}$ Nonetheless, firms that become Petrobras' suppliers have their overall costs increased in order to cope with the requirements of the certifications. This has been stressed by some of the suppliers. They tell that they leave one type of market that takes price as the most important variable and enter another market where quality has an important role.

However, Petrobras also improves product quality of their suppliers. Quality control may be divided into two main procedures: the technical audits for suppliers (ATF) and the Quality Guarantee Program for Services and Materials (PGMQSA). The ATF is composed of inspections that may be more or less intensive during production and delivery of the product, according to the supplier qualification established by the Procurement Department. Usually the intensity is associated to the product line. Suppliers complain a lot about audit procedures saying that they increase their costs. However, they agree that some of the required procedures make their products better.

The PGQMSA has long run targets. The program consists of inspection visits to investigate the application of the state of art techniques of production. The planning of the program required a complete investigation of the state of the art of technology in all covered product lines. After the inspection, each firm receives a grade and this is used by project managers in the choice of companies that will participate of their vendor list. Though some suppliers have lost their certification after implementation, the main objective of the program is to increase the

\footnotetext{
${ }^{3}$ Oliveira and Rocha (2008) tell an anecdote that illustrates this case. One firm had its property structure changed. There were two partners. One of them left the partnership to open one company in the same line of business. The certificate was negotiated as the main part of the deal. Another case was related to an affiliate of a multinational enterprise
} 
compliance of state of the art norms and procedures in order to reduce the number of unconformities in product delivery.

The program has achieved its goal and the number of unconformities has decreased radically with the number of unconformities of PGQMSA covered products per US\$ billion of investment approaching zero (see Rocha 2015). Moreover, the inspections at the PGQMSA served as a consultancy for the companies. Most of them improved their processes during the program. This has been detected by Petrobras' officials in their yearly inspections. One example of the type of impact is the introduction of engineering departments in valve producers in order to be able to calculate and store the signature of produced valves (Oliveira and Rocha 2008).

Petrobras has also a program for the development of new suppliers or the development of new products by existing suppliers. This program is undertaken by the procurement department of Petrobras but may have explicit involvement of internal R\&D personnel and its intention is transference of knowledge required to have to product produced under the adequate conditions. The development of new products together with suppliers is at the center of Petrobras' success in deep waters. One striking case is the subsea equipment that made it possible for Petrobras to achieve its level of production.

There is however one important shortcoming in the relationship of Petrobras with most suppliers located in Brazil. Very rarely knowledge flows go in both ways in a purposeful manner. Mostly Petrobras is directing knowledge to its domestic suppliers. This characteristic makes evident the problems associated with innovative capabilities in the domestic supplying industry. Though suppliers were very likely to acknowledge the importance of Petrobras as source of knowledge, they very rarely pointed out situations where they contributed to innovative gains by Petrobras. Some exceptions occurred in some independent engineering companies and in subsea equipment.

In recent years, the following multinational oil and gas service and equipment supplies companies have established R\&D labs in the Technological Park of the Universidade Federal do Rio de Janeiro: Schlumberger, Baker-Hughes, Halliburton, FMC, Tenaris-Confab, Siemens, General Electrics, Vallourec and Georadar, where the main Petrobras R\&D lab, CENPES, is also located. ${ }^{4}$

Rocha and Urraca Ruiz (2011) analyze the R\&D internationalization strategies of three of these MNC, Schlumberger, Baker-Hughes, and FMC, using patent data and interviews to their CEOs in Brazil and to the CENPES CEO. They argue that three main features have attracted these companies’ R\&D investments to Brazil:

\footnotetext{
${ }^{4}$ Apart from BG.
} 
(i) the size of the pre-salt oil and gas province,

(ii) Petrobras' accumulated capabilities and

(iii) the existence of qualified personnel.

Furthermore, the Petrobras network has also impact on cooperation. Fioravante and Aguirre (2013) show that Petrobras' suppliers are more likely to cooperate with universities and public research labs than a control sample. Rocha and Bueno (2008) show, using Brazilian Innovation Survey for 2003, that oil and gas suppliers have strong innovative behavior when compared to other Manufacturing and Mining companies in Brazil. Nonetheless, they have lower R\&D expenditures. They then explain this behavior due to the larger cooperative relations oil and gas suppliers establish with their clients (Petrobras) and outside industry agents, such as universities.

This narrative shows that Petrobras has a procurement policy that follow most of the instruments or directions proposed by Edquist and Hommen (2000). They provide market for new products, allow firms to supply products in international technological frontier, improve quality patterns and networking across different actors. The main shortcoming seems to be its relation with competitive environments. As De Negri et al. (2011) have shown, firms that supply to Petrobras become less likely to export. This is confirmed by Rocha (2011) in the examination of the quality control program participants. Petrobras seems to absorb their suppliers in their own operations.

\section{DATABASE AND METHOD}

\subsection{THE DATABASE}

The paper uses microdata from Registro Administrativo de Informações Sociais ${ }^{5}$ (RAIS) for the years 2009, 2010 and 2011. RAIS is an administrative register that very employer has to file every year in the Ministry of Labor. It contains social information on employees, such as number of months in workplace, schooling, occupation, date of birth, gender, wage, among other variables. Aggregating this information per firm provides accurate information on the firm level. After aggregating, the whole database contains 2.2 million firms, in 2009, 2.4, in 2010, and 2.5, in 2011.

In order to capture innovative effort, the paper uses a variable represented by the number of employees dedicated to scientific and technical activities (PoTec), selected from the Brazilian Occupation Classification, according to criteria elaborated by Araújo, Cavalcante and Alves (2009). According to Araújo, Cavalcante and Alves (2009), PoTec has a very high correlation to

\footnotetext{
${ }^{5}$ Social Information Administrative Registar.
} 
R\&D expenditures as declared by firms to the Brazilian Innovation Survey (from 0.8 to 0.9 depending on the year tested) and may therefore be used as a proxy for technological activities. In 2011, RAIS registered 573902 scientific and technical employees or 1.2\% of total employees. Previous experience indicates that the attempt to obtain the vendor list of oil and gas supplies companies may conduct to frustration. Therefore, we will use a list of suppliers through the Organização Nacional da Indústria do Petróleo (ONIP), which is an independent non-profit private organization that gathers companies that supply to oil and gas industry. It has cadastral information of the main players in the industry for the year 2007.

In 2011, there were 1150 firms listed in RAIS, 522 were in mining and manufacturing, 126 in construction, two in agriculture, and the remaining in services. Services firms were concentrated in division 74 of ISIC 3, that is, Other Business Activities (205). However, ONIP's list does not by sure meet Petrobras' vendor list. So, in order to control for mistake, the paper only examines firms that supply critical equipment and inputs, that is that belong to the following ISIC 3 divisions: 11 - Extraction of crude petroleum and natural gas, 27 - Manufacture of basic metals, 28 - Manufacture of fabricated metal products, except machinery and equipment, 29 Manufacture of machinery and equipment n.e.c., 30 - Manufacture of office, accounting and computing machinery, 31 - Manufacture of electrical machinery and apparatus n.e.c., 32 Manufacture of radio, television and communication equipment and apparatus, 33 Manufacture of medical, precision and optical instruments, watches and clocks, 34 Manufacture of motor vehicles, trailers, 35 - Manufacture of other transport equipment, 36 Manufacture of furniture; manufacturing n.e.c. These sectors gathered 441 supply companies (according to 2011 RAIS), mostly small and medium sized (see Figure 1).

\section{Figure 1. Distribution of the number of oil and gas suppliers by size, 2011}

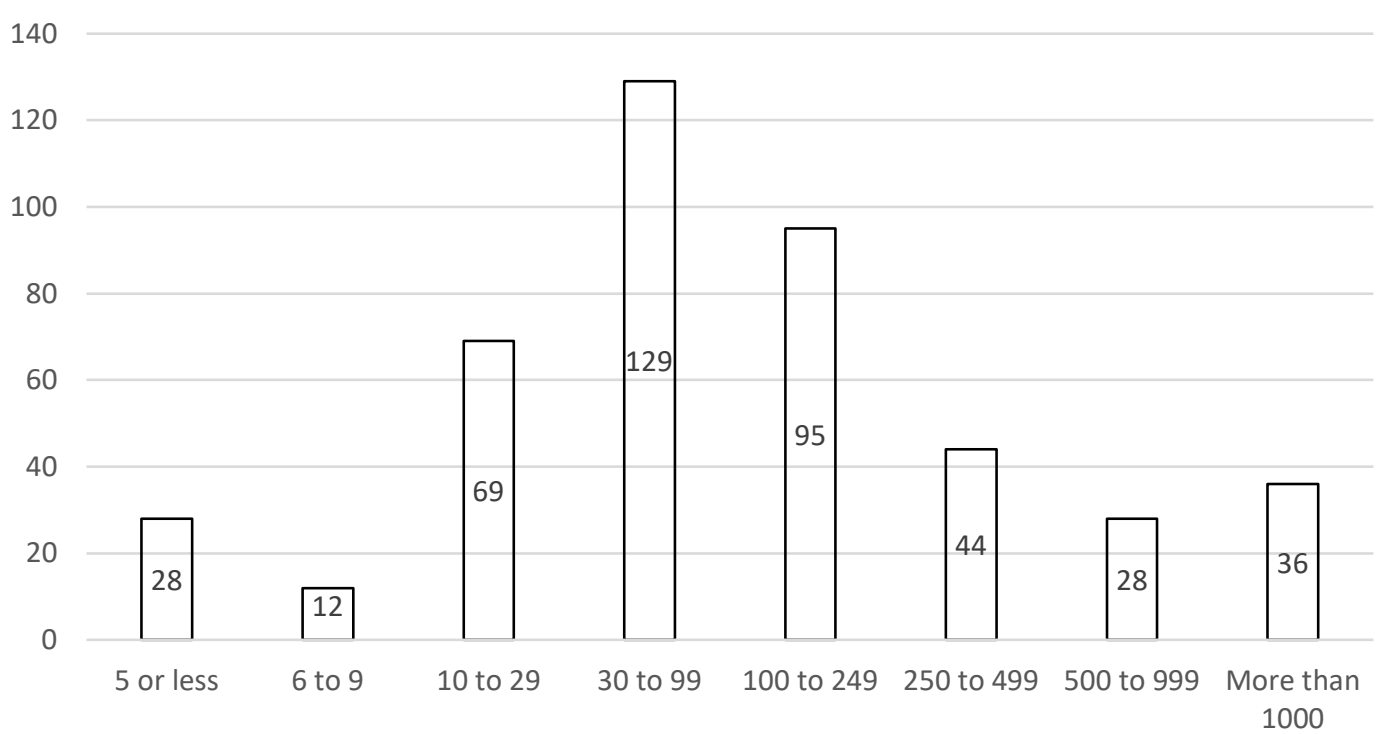




\subsection{THE METHOD}

One important issue to tackle when evaluating governmental innovative policies is selection biases. The aim of government support for innovative activities is to increase innovative activities. Therefore, governmental programs should not fund activities that would happen anyway, but focus on activities that would not occur if governmental funding was not available (Wallsten 2000). In the former case, governmental support would be substitute for private initiatives, while in the latter case it would be complementary.

Selection biases occur first because governmental officials would be inclined to choose firms that they are sure would present results, and therefore focus would be directed to firms that are more likely to carry out innovative activities. A second type of selection bias would emerge from the behavior of innovative firms. In this case, firms would look for the cheapest way to perform innovative activities.

In the case of oil and gas suppliers, the high level of requirements to become a Petrobras supplier may result in similar problems and may have as a consequence biased results, that is, Petrobras suppliers may be better firms because Petrobras selects the best firms in the market and not because Petrobras has influence in their performance.

This kind of problem is tackled in Table 1 that presents descriptive statistics on a set of selected variables for the universe of firms located in critical equipment suppliers' manufacturing sectors - number of employees (nemp), number of employees in scientific and technical occupations (potec), the potec to nemp ratio (inttec), the ratio of number of employees with complete high school education to total employees (capacity), the ratio of the number of employees with superior education to total employees (sup) and wage in terms of the Brazilian minimum wage (wage). It seems clear that equipment suppliers are better firms.

Table 1. Descriptive Statistics, Oil and Gas Suppliers and Non-Oil and Gas Suppliers, 2011

\begin{tabular}{llrrrrrr}
\hline & & nemp & potec & inttec & capacity & wage & sup \\
\hline Non-suppliers & Count & 98936 & 98936 & 98936 & 98936 & 98936 & 98936 \\
& Mean & 27.36 & 0.79 & 0.01 & 0.55 & 2.25 & 0.04 \\
& St. Dev. & 294.97 & 52.02 & 0.04 & 0.37 & 1.66 & 0.12 \\
& Minimum & 1 & 0 & 0 & 0 & 0 & 0 \\
& Maximum & 57459 & 14950 & 1 & 1 & 60.965 & 1 \\
\hline Oil and Guppliers & Count & 441 & 441 & 441 & 441 & 441 & 441 \\
& Mean & 457.83 & 22.83 & 0.04 & 0.69 & 5.17 & 0.16 \\
& St. Dev. & 2138.37 & 109.49 & 0.06 & 0.22 & 3.07 & 0.17 \\
\hline
\end{tabular}




\begin{tabular}{llrrrrrr}
\hline & Minimum & 1 & 0 & 0 & 0 & 0 & 0 \\
\hline \multirow{2}{*}{ Total } & Maximum & 38979 & 1623 & 0.5 & 1 & 18.57157 & 1 \\
& Count & 99377 & 99377 & 99377 & 99377 & 99377 & 99377 \\
& Mean & 29.27 & 0.89 & 0.01 & 0.56 & 2.26 & 0.04 \\
& St. Dev. & 328.16 & 52.44 & 0.04 & 0.37 & 1.68 & 0.12 \\
& Minimum & 1 & 0 & 0 & 0 & 0 & 0 \\
& Maximum & 57459 & 14950 & 1 & 1 & 60.965 & 1 \\
\hline
\end{tabular}

Source: Own elaboration using RAIS.

Different authors have given different answers to the problem of selection bias. Wallsten (2000) uses a three stages least square model with instrumental variable to tackle the endogeneity problem. Gelabert, Fosfuri and Tribó (2009) follows Wallsten (2000) in the use of instrumental variables and adds fixed effects panel as an instrument for controlling for firm specific characteristics. Almus and Czarnitzki (2002) uses propensity score matching. Following Almus and Czarnitzki, a number of studies have introduced propensity score matching to control for selection biases (González and Pazó 2008, Goerg and Strobl 2007, Czarnitzki, Hanel and Rosa 2011).

This paper will adopt propensity score matching in order to compose a control sample and to deal with for selection biases. After composing the control sample, we will run two different models, in a pooled data sample: (i) ordinary least squares and (ii) a tobit model. In this case, we expect to deal with the question whether oil and gas suppliers, submitted to procurement policy, outperform their counterpart.

In order to build a control model, we run a propensity score model that takes into account a number of firm characteristics. The probit pooled model has as dependent variable technological intensity, a dummy variable that assumes value 1 (one) if the firm is an oil and gas supplier and 0 (zero), otherwise, and as independent variables, the concentration level of the three digit sector where the firm is classified, represented by the Hirschman-Herfindhal index (hhi), the firm's wage level (wage), the proportion of employees with complete secondary education (capacity), the average number of years of the employees in the firm (experience), seven size dummies that account for the size level ${ }^{6}$, and sectoral dummies for the two digit secotrs (see equation 1). The results are reported in Table 2. Most importanty, Table 3 shows that differences between treated and untreated samples with respect to size, sector and the other variables are insignificant and, thus, the following analysis will deal with firms that had similar probabilities of being treated.

\footnotetext{
${ }^{6}$ The use of size dummies is justified by the avoidance of testing a quadratic relation between the dependent variable (intec=potec/nemp) and the independent variable that would represent size (nemp).
} 


$$
\begin{gathered}
\text { petro }=\text { constant }+\alpha_{i} \text { sizedummies } \\
+\gamma_{j}+\beta_{1} H H I+ \\
+\gamma_{j} \text { sectoraldummies }
\end{gathered}
$$

(equation 1) 
Table 2. Probit regression

\begin{tabular}{lrrr}
\hline & Coef. & Std. Err. & $\mathrm{z}$ \\
\hline size2 & 0.291 & 0.062 & 4.71 \\
size3 & 0.675 & 0.046 & 14.76 \\
size4 & 1.137 & 0.045 & 25.43 \\
size5 & 1.549 & 0.049 & 31.57 \\
size6 & 1.639 & 0.060 & 27.37 \\
size7 & 1.802 & 0.074 & 24.31 \\
size8 & 1.961 & 0.071 & 27.73 \\
hhi & -0.631 & 0.256 & -2.47 \\
remmediadez & 0.037 & 0.003 & 10.9 \\
experience & 0.005 & 0.000 & 18.65 \\
capacity & 0.339 & 0.049 & 6.93 \\
sector27 & -0.269 & 0.118 & -2.27 \\
sector28 & -0.343 & 0.116 & -2.96 \\
sector29 & -0.034 & 0.114 & -0.3 \\
sector30 & -0.173 & 0.141 & -1.22 \\
sector31 & -0.071 & 0.116 & -0.61 \\
sector32 & -0.399 & 0.132 & -3.02 \\
sector33 & -0.130 & 0.122 & -1.06 \\
sector34 & -1.134 & 0.141 & -8.02 \\
sector35 & -0.073 & 0.122 & -0.6 \\
sector36 & -1.086 & 0.138 & -7.87 \\
_cons & -3.585 & 0.128 & -28.05 \\
& & & \\
N & 277595 & & \\
LR chi & 4779 & & \\
Pseudo R2 & 0.2851 & & \\
\hline & & &
\end{tabular}


Table 3. Mean differences between treated and untreated samples

\begin{tabular}{lrrrrrr}
\hline & \multicolumn{3}{c}{ Mean } & & \multicolumn{2}{c}{ t-test } \\
\cline { 2 - 4 } \cline { 5 - 7 } Variable & Treated & Control & \%bias & & $\mathrm{t}$ & $\mathrm{p}>|\mathrm{t}|$ \\
\hline size2 & 0.03272 & 0.03729 & -1.6 & & -0.64 & 0.524 \\
size3 & 0.16971 & 0.16058 & 2.3 & & 0.63 & 0.529 \\
size4 & 0.29072 & 0.28615 & 1.2 & & 0.26 & 0.796 \\
size5 & 0.21918 & 0.22983 & -3.4 & & -0.65 & 0.513 \\
size6 & 0.0997 & 0.10578 & -2.8 & & -0.51 & 0.607 \\
size7 & 0.05784 & 0.05327 & 2.6 & & 0.51 & 0.61 \\
size8 & 0.07991 & 0.07686 & 1.5 & & 0.29 & 0.772 \\
hhi & 0.03056 & 0.03088 & -0.6 & & -0.12 & 0.904 \\
experience & 59.879 & 60.304 & -1.2 & & -0.26 & 0.793 \\
capacity & 0.6713 & 0.67733 & -2 & & -0.66 & 0.509 \\
remmediadez & 5.0697 & 5.0154 & 2.2 & & 0.34 & 0.733 \\
hhi & 0.03056 & 0.03088 & -0.6 & & -0.12 & 0.904 \\
sector27 & 0.06849 & 0.06393 & 2 & & 0.47 & 0.638 \\
sector28 & 0.20548 & 0.21689 & -2.6 & & -0.72 & 0.474 \\
sector29 & 0.40944 & 0.40183 & 1.7 & & 0.4 & 0.691 \\
sector30 & 0.01903 & 0.02588 & -6.1 & & -1.18 & 0.236 \\
sector31 & 0.1309 & 0.11872 & 4.3 & & 0.94 & 0.345 \\
sector32 & 0.02283 & 0.02588 & -2.2 & -0.51 & 0.613 \\
sector33 & 0.0586 & 0.06545 & -3.2 & -0.73 & 0.467 \\
sector34 & 0.01294 & 0.00989 & 1.8 & 0.73 & 0.463 \\
sector35 & 0.03349 & 0.03729 & -2.5 & -0.53 & 0.598 \\
sector36 & 0.01218 & 0.01446 & -0.7 & -0.51 & 0.61 \\
\hline
\end{tabular}

After defining the control sample, we'll test the following equation:

inttec $=$ constant $+\alpha_{i}$ sizedummies ${ }_{i}+\beta_{1}$ petro $+\beta_{2} H H I+\beta_{3}$ capacity + $\beta_{4}$ experience $+\gamma_{j}$ sectoraldummies (Equation 2)

We'll report the results for the OLS model in pooled data and panel data random effects model and for tobit model, also in pooled data and panel data random effects model. The use of tobit model is justified due to the censured dependent variable in zero and one. Equation (2) departs from the basic Schumpeterian model, relating innovation efforts to firm size and market concentration. The use of sectoral dummies is justified to control for opportunity and appropriability characteristics. Firm characteristics are also accounted for in experience and capacity variables. Petro is the policy variable to be tested. 


\section{RESULTS}

Table 4 shows the four regressions equations. The first model shows an OLS pooled data regression; the second, a panel data random effects regression; the third, a tobit pooled data regression; and the fourth model, a random effects tobit panel data regression. The results of all four equations confirm both Schumpeterian hypothesis. Larger firms dispend greater efforts in technological activities. The higher the maker concentration, the higher the technological efforts and firm capacity and employee experience seem to be positive correlated with technological effort. Most sectoral dummies are significant with higher effects in instruments (33), electrical equipment (32) and oil and gas extraction (11).

The petro dummy has the expected sign. Relation with oil and gas procurement policy has positive effect on technological effort, always significant at the $1 \%$ level. The dimension of the effect varies from 0.9 percentage point, in the OLS model up to $2.5 \%$ percentage point in the random effects tobit panel data model. In the case of both tobit models the effect is substantial, suggesting that oil and gas procurement policy has been quite effective. The analysis of the four models and the adequacy of the tobit model to the situation, suggests that the impact should be closer to $2 \%$. This impact is far from small. It more than doubles the technological efforts in relation to similar firms in size, capacity, experience, markets and sectors.

The results point to a great influence of Petrobras' procurement on firm behavior. This influence had been assessed before with respect to firm growth and exports (De Negri et al. 2011) with mixed results. This analysis adds important feature to it because it shows that technological activities are also affected.

However, the result also throws some doubts on the way innovation policy has been carried out in Brazil. Though Petrobras has been able to develop a thick and high performance networks of firms, universities and research labs, the results seem to be much more a consequence of the company's initiative than a result of governmental policy. As Rocha (2015) argues, only very recently resources from the supply side have been channeled towards the oil and gas equipment supplies firms. From the great amount of public resources directed to R\&D and S\&T activities in the oil and gas sector, very little has been focused on suppliers. Money has mostly been directed towards CENPES (the Petrobras R\&D lab) and universities and non-profit research facilities. A greater connection between demand and supply instruments may be called for and seems to be an important challenge to pursue.

Most importantly, in a scenario where Petrobras, national content policy and state-owned companies are under great attack, this result points to important spillovers of the presence of Petrobras and the role of policy guided measures carried out by the company. 
Table 4. Regressions

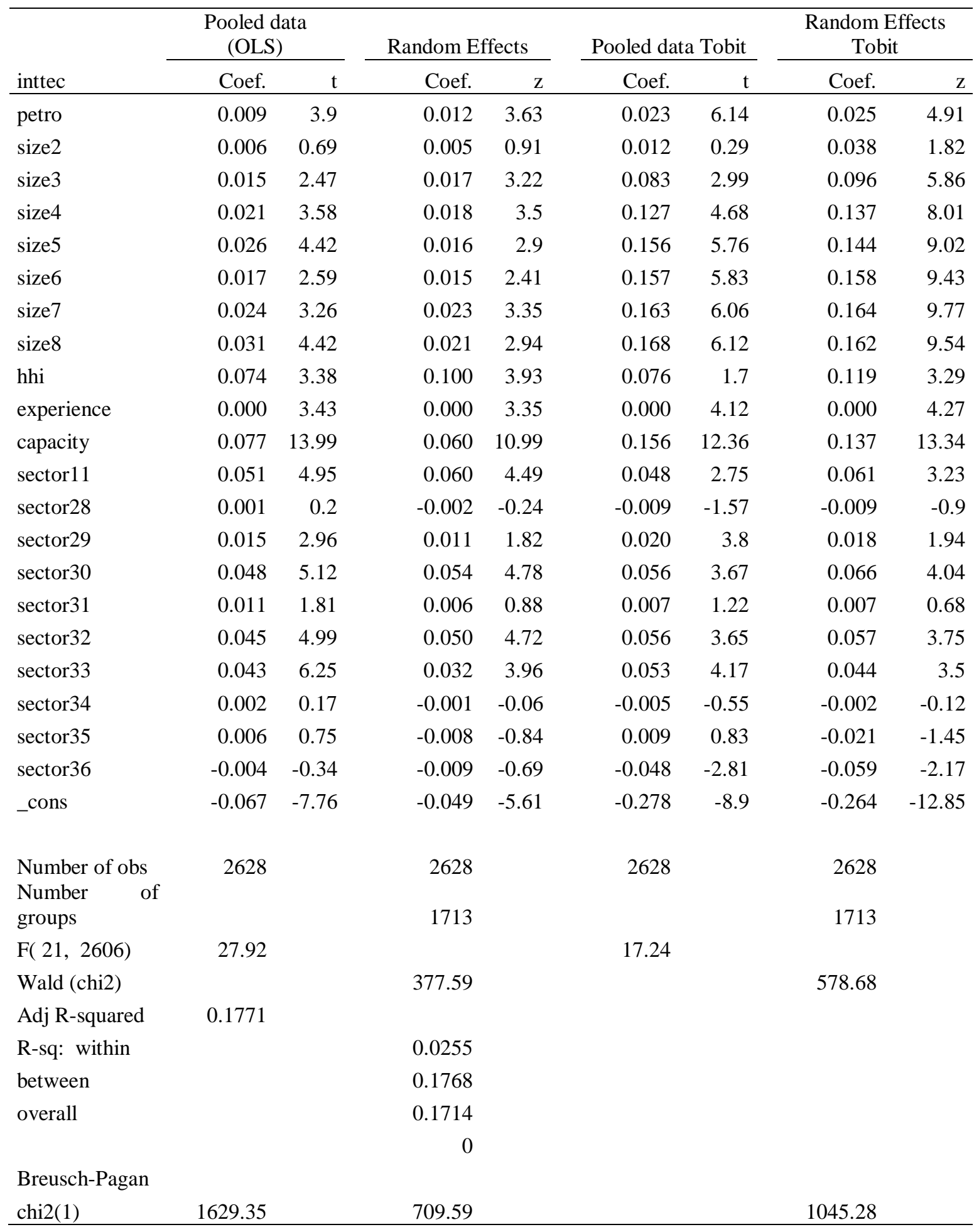

\section{CONCLUSIONS}

This paper aimed to assess the impact on firms of the national content in the oil and gas sector and the procurement policy carried out by Petrobras. Using data from RAIS, the paper carried 
out this task by comparing the ratio of scientific and technical personnel to total number of employees of oil and gas equipment supplies firms and a control sample built through propensity score matching. The results suggest that being a supplier to the sector improves firm's technological intensity.

Recent literature on innovation policy has argued that procurement policies that explore more interactions across agents are an important policy option. They pose that supply based policies are based on a market imperfection view of innovation while procurement policies explore the interactive character of innovative activities and, together with demand instruments, may provide better results. This paper presents support to their cause.

\section{REFERENCES}

1. Almus, M., Czarnitzki, D., 2003. The effects of public R\&D subsidies on firms’ innovation activities? Journal of Business and Economic Statistics 21 (2), 226-236.

2. ANP (2012) Local content in Brazilian oil \& gas industry. http://www.anp.gov.br/?id=554.

3. Araújo, B. C.; Cavalcante, L. R.; Alves, P. (2009) "Variáveis proxy para os gastos empresariais em inovação com base no pessoal ocupado técnico-científico disponível na Relação Anual de Informações Sociais (RAIS)”, Radar: Tecnologia, Produção e Comércio Exterior, Brasília, n. 5, p. 16-21.

4. Block F, (2008) Swimming against the current: the rise of a hidden developmental state in the US. Politics and Society 3(2).

5. BNDES (2014) Perspectivas do Investimento. http://www.bndes.gov.br/SiteBNDES/export/sites/default/bndes_pt/Galerias/Arquivos/c onhecimento/perspectivas investimentos/boletim perspectivas maio2014.pdf.

6. Czarnitzki, D., Hanel, P., Rosa, J.M., 2011. Evaluating the impact of R\&D tax credits on innovation: amicroeconometric study on Canadian firms. Research Policy 40 (2), 217-229.

7. De Negri, J.; Silva, A. Correia, L. Aguirre, L. Alves, P. O Impacto da Petrobras nos seus fornecedores. Em IPEA (2011) Poder de Compra da Petrobras: Impactos Econômicos nos seus Fornecedores. IPEA, Brasília. http://www.ipea.gov.br/portal/index.php?option=com_content\&view=article\&id=6477.

8. De Oliveira, A. and Rocha, F. (2008) Conclusões e Políticas. Final Report to the study Competitividade dos Fornecedores da Indústria Nacional do Petróleo e Gás, INDP\&G 28. http://www.prominp.com.br/prominp/pt_br/projetos/projetos.htm.

9. Edler, J.,Georghiou,L.,2007.Public procurement and innovation? Resurrecting the demand side. Research Policy 36 (7), 9 49-963. 
10. Edquist, C., Hommen, L., 2000. Public technology procurement and innovation theory. Public Technology Procurement and Innovation 16, 5-70.

11. Edquist, C., Hommen, L., Tsipouri, L., 2000. Introduction. Public Technology Procurement and Innovation, vol. 16. Springer.

12. Fioravante, D. G. and Aguirre, L. (2013) A cooperação entre universidades e empresas e os fornecedores da Petrobras. Turchi, L.; De Negri, J. and De Negri, F. (2013) Impactos Tecnológicos das Parcerias da PETROBRAS com Universidades, Centros de Pesquisa E Firmas Brasileiras, Ipea, Brasília, http://www.ipea.gov.br/portal/images/stories/PDFs/livros/livros/livro_impactos_tecnolo gicos_parcerias.pdf.

13. Gelabert, l., Fosfuri, a. and Tribó, J. (2009) Does the effect of public support for R\&D depend on the degree of appropriability? The Journal of Industrial Economics, LVII (4), 736-767.

14. Geroski, P., 1990. Procurement policy as a tool of industrial policy? International Review of Applied Economics 4 (2), 182-198.

15. Goerg, H., Strobl, E., 2007. The effect of R\&D subsidies on private R\&D? Economica 74 (294), 215-234.

16. González, X., Pazó, C., 2008. Do public subsidies stimulate private R\&D spending? Research Policy 37 (3), 371-389.

17. Guerzoni and Raiteri (2015) Demand-side vs. supply-side technology policies:Hidden treatment and new empirical evidence on the policy mix. Research Policy 44, 726-747.

18. Lichtenberg, F.R., (1987). The effect of government funding on private industrial research and development: a re-assessment. The Journal of Industrial Economics 36, 97-104.

19. Lichtenberg, F.R., (1988). The private R\&D investment response to federal design and technical competitions. American Economic Review 78, 550-559.

20. Lichtenberg, F.R., Siegel, D. (1991). The impact of R\&D investment on productivity new evidence using linked R\&D-LRD data. Economic Inquiry 29, 203-228.

21. Mazzucato, M. (2011) The Entrepreneurial State. http://www.demos.co.uk/files/Entrepreneurial State - web.pdf.

22. Peilei, F. (2006) Promoting Indigenous Capability: The Chinese Government and the Catching-Up of Domestic Telecom-Equipment Firms. China Review, Spring 2006, v. 6, iss. 1, pp. 9-35.

23. Porto, G.; Turchi, L; and Rezende,P. (2013) Radiografia das parcerias entre PETROBRAS e as ICTs Brasileiras: uma análise a partir da ótica dos coordenadores de projetos tecnológicos. Em Turchi, L.; De Negri, J. and De Negri, F. (2013) Impactos Tecnológicos das Parcerias da PETROBRAS com Universidades, Centros de Pesquisa e 
http://www.ipea.gov.br/portal/images/stories/PDFs/livros/livros/livro_impactos_tecnolo gicos_parcerias.pdf.

24. Rocha, F. (2011) O Desempenho dos Participantes no Programa de Garantia de Qualidade de Materiais e Serviços Associados. IPEA (2011) Poder de Compra da Petrobras: Impactos Econômicos nos seus Fornecedores. IPEA, Brasília. http://www.ipea.gov.br/portal/index.php?option=com_content\&view=article\&id=6477.

25. Rocha, F. (2015). Recursos naturales como alternativa para la innovación tecnológica: petróleo y gas en Brasil. http://www19.iadb.org/intal/intalcdi/PE/2015/15676.pdf.

26. Rocha, F. e Urraca Ruiz (2011) The role of the network coordinator in the attraction of foreign investments in R\&D: The case of the Brazilian oil and gas industry. Transnational corporations, 20, 33-60.

27. Turchi, L.; De Negri, J. and De Negri, F. (2013) Impactos Tecnológicos das Parcerias da PETROBRAS com Universidades, Centros de Pesquisa e Firmas Brasileiras, Ipea, Brasília,

http://www.ipea.gov.br/portal/images/stories/PDFs/livros/livros/livro impactos tecnolo gicos parcerias.pdf.

28. WALLSTEN, S. (2000) The effects of government-industry R\&D programs on private R\&D: the case of the Small Business Innovation Research program. RAND Journal of Economics Vol. 31, No. 1, Spring. 